\title{
The use of digital videos in Edpuzzle and its influence on the performance of Accounting students at a brazilian public institution
}

O uso de vídeos digitais no Edpuzzle e sua influência no desempenho dos alunos de Ciências

Contábeis de uma instituição pública brasileira

El uso de videos digitales en Edpuzzle y su influencia en el desempeño de estudiantes de Contabilidad en una institución pública brasileña

Received: 04/01/2021 | Reviewed: 04/11/2021 | Accept: 04/14/2021 | Published: 04/29/2021

Ana Carolina da Costa
ORCID: https://orcid.org/0000-0001-9788-8322
Uningá University Center, Brazil
E-mail: anacarolcostta@gmail.com
Breno Gabriel da Silva
ORCID: https://orcid.org/0000-0002-8322-9235
University of São Paulo, Brazil
E-mail: brenogsilva@ @usp.br
Yana Miranda Borges
ORCID: https://orcid.org/0000-0002-1866-5524
on, Science and Technology of Amazonas, Brazil
E-mail: borges.yana@gmail.com
Cláudio Marques
ORCID: https://orcid.org/0000-0001-5715-3014
State University of Maringá, Brazil
E-mail: cmarquesuem @ gmail.com

\begin{abstract}
The objective of this study was to verify the influence of digital videos, using the Edpuzzle tool, on the performance of accounting students. This technological resource was used in four subjects of the Accounting Science Course through the students cell phones. The research used a quantitative approach, with the participation of 164 students. The study consisted of a quasi-experiment, with two tests being applied, called pre-test and post-test, in order to compare the performance between the control and experimental groups. The statistical results indicated that there were no significant differences between the groups, similar information was obtained when crossing between the pretest and post-test scores. The findings, despite not confirming the hypothesis of improvement in academic performance with the use of technology and, especially the videos conducted in Edpuzzle, suggest that there was significant motivation and satisfaction on the part of students in carrying out the requested tasks. Considering the limitations of the research, specifically in relation to the context and the period of application, it can be said that its main contribution was the perception that the use of a certain technology in the classroom, by itself, does not improve performance and that more studies are needed with different methodological approaches and in extended periods and samples.
\end{abstract}

Keywords: Accounting education; Teaching; Academic achievement; Quasi-experiment; Technology in teaching; Digital video.

\footnotetext{
Resumo

O objetivo deste estudo foi verificar a influência dos vídeos digitais, utilizando a ferramenta Edpuzzle, no desempenho dos discentes de contabilidade. Este recurso tecnológico foi usado em quatro disciplinas do Curso de Ciências Contábeis por meio dos celulares dos estudantes. A pesquisa fez uso de abordagem quantitativa, contando com a participação de 164 discentes. O estudo consistiu na realização de um quase-experimento, sendo aplicadas duas provas, designadas pré-teste e pós-teste, com o intuito de comparar o desempenho entre os grupos de controle e experimental. Os resultados estatísticos indicaram que não houve diferenças significativas entre os grupos, informações análogas foram obtidas quando fez-se os cruzamentos entre as notas dos pré-testes e pós-testes. Os achados, apesar de não confirmar a hipótese de melhoria no desempenho acadêmico com a utilização de tecnologia e, em especial os vídeos conduzidos no Edpuzzle, sugerem que houve significativa motivação e satisfação por parte dos alunos na realização das tarefas solicitadas. Considerando as limitações da pesquisa, especificamente em relação ao contexto e ao período de aplicação, pode-se dizer que sua principal contribuição foi a percepção de que a utilização de
} 
uma determinada tecnologia na sala de aula, por si só não melhora o desempenho e que são necessários mais estudos com diferentes abordagens metodológicas e em períodos e amostras ampliadas.

Palavras-chave: Educação contábil; Ensino; Desempenho acadêmico; Quase-experimento; Tecnologia no ensino; Vídeo digital.

\section{Resumen}

El objetivo de este estudio fue verificar la influencia de los videos digitales, utilizando la herramienta Edpuzzle, en el desempeño de los estudiantes de contabilidad. Este recurso tecnológico se utilizó en cuatro asignaturas del Curso de Ciencias Contables a través de los teléfonos celulares de los estudiantes. La investigación utilizó un enfoque cuantitativo, con la participación de 164 estudiantes. El estudio consistió en un cuasi-experimento, con la aplicación de dos pruebas, llamadas pre-test y post-test, con el fin de comparar el desempeño entre los grupos control y experimental. Los resultados estadísticos indicaron que no hubo diferencias significativas entre los grupos, se obtuvo información similar al cruzar entre los puntajes pre-test y post-test. Los hallazgos, a pesar de no confirmar la hipótesis de mejora en el rendimiento académico con el uso de la tecnología y, especialmente, los videos realizados en Edpuzzle, sugieren que hubo una motivación y satisfacción significativa por parte de los estudiantes en la realización de las tareas solicitadas. Considerando las limitaciones de la investigación, específicamente en relación al contexto y al período de aplicación, se puede decir que su principal aporte fue la percepción de que el uso de una determinada tecnología en el aula, por sí solo, no mejora el desempeño y que se necesitan más estudios con diferentes enfoques metodológicos y en períodos y muestras extensos.

Palabras clave: Enseñando; Educación contable; Logro académico; Cuasi-experimento; Tecnología en la enseñanza; Video digital.

\section{Introduction}

The use of technology has grown significantly, with emphasis on efforts to increase access to quality education, having a transformational impact on teaching and learning, through the integration of new mechanisms that endorse its use as an educational tool (Watty, Mckay \& Ngo, 2016). Progress related to the technological field involving infrastructure, communication, equipment and online tools facilitates the development of classroom teaching, corroborating to connect students to their courses, their profession, themselves and their teachers (Lillie \& Wygal, 2011; Holtzblatt \& Tschakert, 2011).

The combination of technologies and teaching has been generating reflexes in learning, which serve as elements for the satisfaction and performance of students (Quintana, 2015). In this sense, such methods have been causing changes in the educational scenario, including accounting education, which has undergone changes regarding both the practices (both with regard to the practices) of the profession as well as academic learning methods (Lillie \& Wygal, 2011). Thus, the objective became the search for balance between the labor market, interest of students and teachers and adaptations by educational institutions to new technological resources (Holtzblatt \& Tschakert, 2011).

Faced with this scenario, change initiatives on the part of universities began to occur. They observed that the technological mechanisms used mainly in classroom courses promote an increase in flexibility through resources that facilitate learning, anytime and anywhere (Sharoff, 2011). There is an expressive growth in the insertion of technological resources in the classrooms, being justified by the belief that it is more suitable to encourage learning among students (Nicol, Owens, Le Coze, MacIntyre \& Eastwood, 2018).

Investigations have shown that the use of digital media is responsible for significantly affecting students skills, preferences and attitudes (Thompson, 2013), directly impacting the Generation $\mathrm{Z}$ formation, or digital natives, which corresponds to those born between 1995 and 2012 (Singh, 2014), this being the first generation born in a world connected to the internet and in the smartphone era (Williams, 2015). Digital natives have been experiencing constant technological advances, with emphasis on the use of mobile technology connected to the internet. It is noticed, therefore, that traditional education needs improvement, considering the use of online platforms, mobile devices and new teaching strategies (mobile learning) (Berwanger, 2019).

Thus, it is noted that there are different tools that can be used in the transmission of digital videos, and it is in this 
scenario that Edpuzzle <https://edpuzzle.com/> stands out for its versatility involving audiovisual content (Pueo, Olmedo, Penichet-Tomás \& Carbonell, 2017). It is a platform that allows teachers to make edits to videos, insert evaluation quizzes and comments on texts relevant to the content (Baker, 2016). Furthermore, it is observed that few studies have been carried out on this tool in previous accounting literature, and the analyzes by Serçemeli, Günbaş \& Baydaş (2018) point to satisfactory preliminary results among accounting students, which encourages more research involving this subject purpose. It is reasonable to consider, therefore, investigations that support the use of educational devices and tools that favor and stimulate the teaching/learning of students, thus seeking more technological tools that are effective for accounting education.

Thus, considering the potential of mobile digital technologies verified in previous studies (Nasu, 2017; Palma, Tobías, Prieto, León, \& Ruiz, 2018; Berwanger, 2019; da Silva et al., 2020), and the effects of the Edpuzzle tool on the improvement of digital videos and the positive receptivity of students (Pueo et al., 2017; Mischel, 2018), the present study proposes to analyze the following research question: What is the influence of the use of digital videos, using the Edpuzzle tool, on the performance of Accounting Sciences students from a Brazilian public education institution?

In addition, it is argued that research involving digital videos shows positive effects among accounting students, presenting satisfactory results regarding their performance and time management (Lubbe, 2016), motivation in activities (Holtzblatt and Tschakert, 2011) and satisfaction (Serçemeli et al., 2018). The present study, however, seeks to bring new results not yet verified in the current literature, considering that previous studies that adopted the quasi-experiment with accounting students were not verified, conducting digital videos in the Edpuzzle tool by their smartphones.

Thus, what is intended to be added to current knowledge is new checks on students performance in the face of the use of a technological resource that is still little explored in the accounting literature, given that the initial results have already been verified in the research by Serçemeli et al. (2018). In turn, this study seeks, using the quasi-experiment methodology, to contribute with new findings and directions, bringing unprecedented perspectives for both teachers and educational managers, serving as a stimulus for new didactic methodologies that directly impact their students.

\section{Material and Methods}

\subsection{Student performance with the use of videos in Edpuzzle and development of the Hypothesis}

The presence of digital videos in learning environments presents itself as an evolving reality, according to the study carried out by Pearson Learning Solutions and the Babson Survey Research Group, in 2011. Videos are the most common types of social media used in classes, and it was found that $80 \%$ of the teachers who participated in the survey said they had already used this technology during their classes (Moran, Seaman \& Tinti-Kane, 2011).

Likewise, Holtzblatt and Tschakert (2011) assure that digital videos are, in fact, important educational tools, being able to attend students learning styles, going beyond those provided by traditional classes, which favor the aural, reading and writing style, studied by Fleming (1995). Videos can provide the opportunity to stimulate visual, auditory and kinesthetic learners (Fleming, 1995), since both senses are stimulated at the same time (Holtzblatt \& Tschakert, 2011).

Exploring the application of digital videos as a technological tool in accounting education becomes pertinent in the face of such studies, since previous research indicates that accounting students are increasingly disinterested or discouraged to study (Phang, Johl \& Cooper, 2014). Although the use of educational technology is evolving towards accounting education, more research is needed in this regard, to understand how they can promote learning in accounting (Apostolou, Dorminey, Hassell \& Watson, 2013).

Another point to be considered refers to the adoption of educational technologies to be considered slow in accounting education. This reality occurs due to several factors, ranging from workload to the preference for traditional teaching methods, which become even more expressive due to the reluctance of the faculty to adopt new technologies (Watty et al., 2016). And, 
although it has been found that the use of videos in education is deficient in terms of exploiting their media characteristics (Laaser \& Toloza, 2017), further studies in this regard are pertinent to the accounting literature, in view of the positive results verified in previous studies.

And yet, considering that student involvement is fundamental for learning (D'Aquila, Wang \& Mattia, 2019), studies covering the technological tool of digital videos in classroom environments point to stimulating perspectives with regard to accounting education, presenting positive results in motivational aspects (Holtzblatt \& Tschakert, 2011) and in performance (D'Aquila et al., 2019; da Silva et al., 2020). This study, however, innovates by testing the reflexes of the Edpuzzle tool, in the performance of students, conducted on smartphones, through a quasi-experiment study.

Edpuzzle, therefore, refers to a resource in which teachers can transform any video into an interactive and engaging class, which can be selected on online sites, such as YouTube, or even insert a personal video, which can also be edited within the platform (Alvarado, Coelho, \& Dougherty, 2016). After choosing the video, Edpuzzle offers a variety of options that allow editing, in order to complete the students knowledge, including: cut and quizzes that can be inserted in different sections (Afach et al., 2018; Mischel, 2018 ).

It is noteworthy that this technological resource is sometimes used passively in teaching, thus, students only watch the media without actually presenting active learning (Graham, 2016). In this logic, Kolås (2015) adds that traditional videos leave students as passive spectators, while interactive videos include the use of quizzes and special editions, involve the student and demand more of their attention. And it is in this perspective that the technological tool Edpuzzle excels in learning environments, becoming representative, and yet, this tool deserves to be highlighted for being a free online source for sharing videos (Mischel, 2018).

Among the most diverse mechanisms and tools that can be used in learning environments, mobile devices have been shown to be widely available because they are more acessible, convenient and less expensive for students (Wu et al., 2012). Thus, amid the vast variety of technologies that can be used as instructional tools, mobile learning or m-learning, is being addressed as one of the main trends in the application of new technologies in education (Pasiar, 2018 ).

Surely one of the central objectives of higher education institutions refers to the learning of students, which is a question directly linked to the use of teaching (Cruz, Corrar \& Slomski, 2008). It is argued that the educational process in accounting, as well as in all other courses, is intended to achieve high quality results in education (Booth, Luckett \& Mladenovic, 1999). Thus, in order for these goals to be achieved, it is necessary to have knowledge about the factors that influence academic performance, contributing to the direction of implications that can influence learning (Magdalena, 2015). And in that perspective, this study will be limited to analyzing the insertion of technology in education and its reflexes on performance, establishing as a research hypothesis:

\section{H1: Students submitted to the use of digital technologies have higher performance in classroom activities.}

In this way, and consistent with the statement by Holtzblatt and Tschakert (2011), it is likely that teachers will use more and more videos in their didactic content, so it is essential to measure the performance of learners, contributing to the literature and new findings for accounting learning. The present research contains two phases in its development: (1) initial phase of the quasi-experimental design: moment when the surveys were carried out to configure the structure of the quasiexperiment and resumed the research hypotheses raised in the theoretical framework; (2) phase of execution of the quasiexperiment: proceeded with the application of the established quasi-experiment, in order to achieve the objectives and test the previously determined hypothesis.

\subsection{Initial Phase of Quasi-Experimental Design}

The research method used was the quasi-experiment, a type of empirical study that had a non-random distribution 
between control groups (CG) and experimental groups (EG) (Gall, Gall \& Borg, 2003). Soon in the initial phase, it was noted the impossibility of random distribution of participants to the designated groups (experimental and control) due to structural and institutional factors. Thus, although the importance of randomness for experimental methods of the Higher Education Institution (HEI) selected for this study is recognized (Cozby \& Bates, 2012), the present research was developed as a quasiexperimental design, being adapted according to Gall et al. (2003) and Smith (2003). The factor responsible for this attribution stems from the impossibility of random distribution, which normally occurs in field studies.

In this configuration, the participants (students of the Accounting Sciences course) were not randomly distributed among the CG, composed of students who had no contact with Edpuzzle technology, and the EG, which comprise students who had contact and use of Edpuzzle technology. Both groups were submitted to a pre-test and a post-test, the present design being structured based on the Nonequivalent Control-Group Design (Gall, et al., 2003).

The pre-test was developed with the intention of obtaining information about the students prior knowledge in relation to the content taught on the day of the post-test, even if the groups were not equivalent. The changes were verified in the pretest to the post-test scores (Cozby \& Bates, 2012). Thus, both the CG and the EG performed the pre-test, which corresponds to an initial test applied at the beginning of the class, using the traditional method "paper and pen". This was done with the intention of verifying the students previous knowledge regarding the content that would be taught on the day of applying the post-test.

It is emphasized that the post-test corresponds to a test applied at the end of the class, after the teacher has taught the content of the test. The CG performed the post-test without the insertion of any technology. The test was also carried out using the traditional "paper and pen" method EG performed the post-test with the use of technology. The test was developed on the Edpuzzle application platform on each students smartphone. The video content was related to the subject taught on the day of the post-test, just as it was done in the CG. At the end of the video, the test questions were automatically made available within the video viewed by the student.

In the CG, students took the test using the traditional "paper and pen" method, both in the pre-test and in the post-test. At EG, the students answered the post-test questions in the Edpuzzle application. The two classes that formed the CG and the EG maintained, both in the pre-test and in the post-test, the classes taught by the same teacher, lasting for a class of 30 minutes in the pre- test, and in the post-test of two classes of 50 minutes each. The test questions were directly related to the content taught on the day of the post-test, which was unpublished for the students. It is also noteworthy that the same questions were applied both in the pre-test and in the post-test, with the intention of measuring the level of knowledge effectively acquired by the students of both groups. Between the application of the pre-test to the post-test, an interval of one to two weeks was established, thus seeking to avoid that the students responses were not the result of repetition or memorization. The use of quasi-experimental methodology can also be verified with evolutionary directions in the Brazilian accounting literature. For example, Nasu (2017) and Quintana (2015) continued with the central objective of testing the impact of the insertion of new technologies in education. Thus, the quasi-experimental design of this research is shown in Figure 1. 
Figure 1. Quase-experimental design.

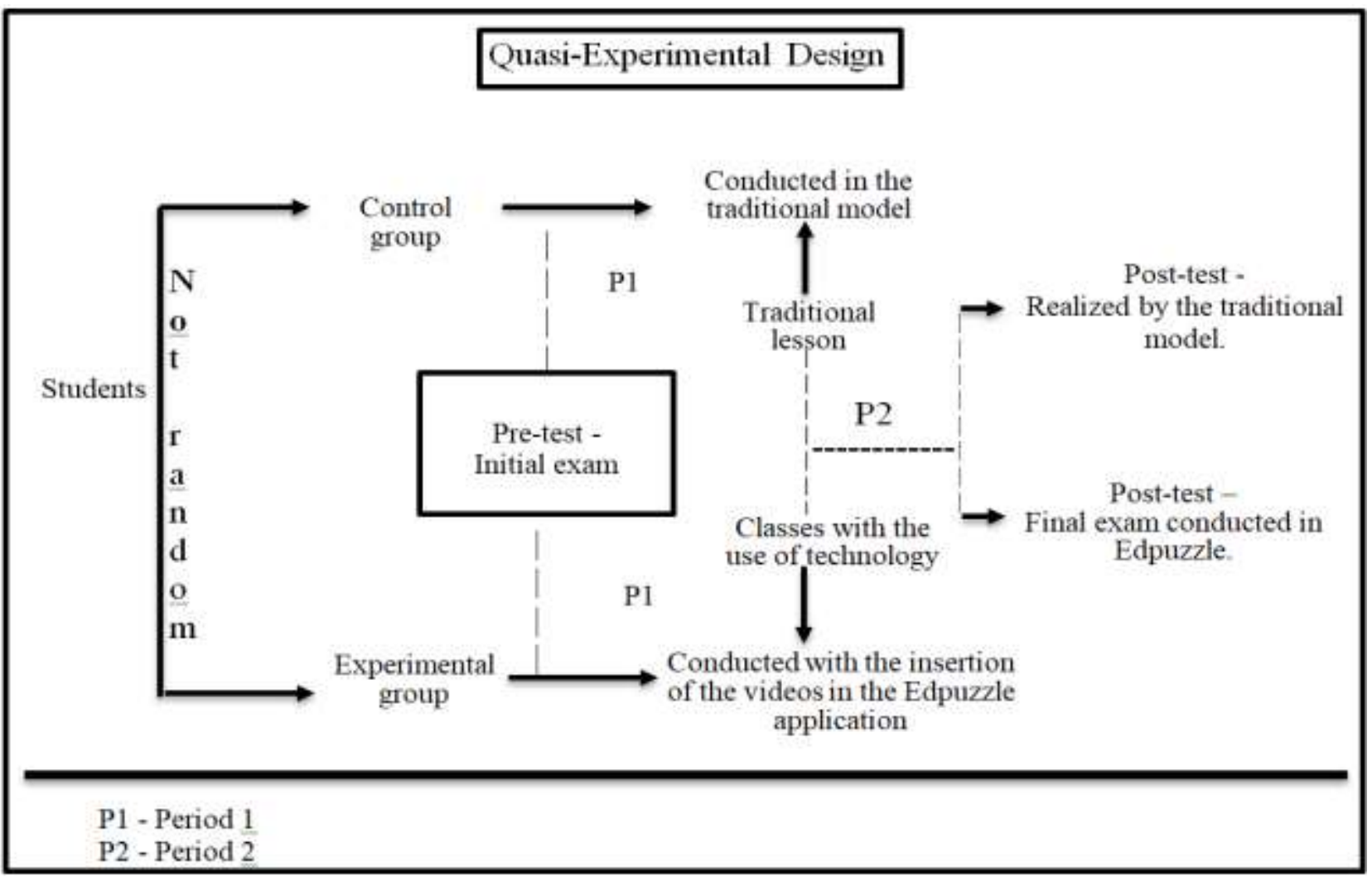

Note: Adapted according to Nonequivalent Control-Group Design (Gall, et al., 2003). Source: Authors.

After establishing the quasi-experimental design and substantiating the hypothesis raised in the theoretical framework, it was verified whether there are positive relationships between the insertion of digital videos in the learning process and the students performance in the exams.

Table 1. Study variables.

\begin{tabular}{c|c}
\hline Independent variable & Dependent variables \\
\hline Technologies inserted in education & Performance \\
(Digital videos conducted in the Edpuzzle application) & . \\
\hline
\end{tabular}

Source: Authors.

The independent variable used for the experimental manipulation was the insertion of technology in the classroom through the use of digital videos in the Edpuzzle application on smartphones, similar to the achievements of Palma et al. (2018). Additionally, Gall et al. (2003) state that usually experimental research in the field of education is intended to test the effect of an independent variable, which is sometimes configured with a new educational practice or product (applications, chats, forums, etc.) on important results, such as student performance, attitude or self-concept. Given the configurations of the quasi-experimental design, the next sections present in detail the evolutionary stages of this quasi-experiment.

\subsubsection{Execution phase of the Quasi-Experiment}

Outlining the initial steps and adjusting the model to be executed, data collection started. For this purpose, two groups were maintained in each of the investigated classes, and the quasi-experiment was developed at two different times. Initially, we proceeded with the pre-test, which corresponds to an initial test applied at the beginning of each class, before the teacher 
starts the day's content, serving as a way to verify the students prior knowledge about the content that would be taught in the post-test. At this time, the socioeconomic questionnaire was also applied, consisting of multiple choice questions, in order to verify the profile of each sample studied. Subsequently, after a period of time between one to two weeks, the post-test was conducted. At that moment, the teacher taught the class, explaining the content corresponding to the test performed in the pretest and, later, at the end of the class, the test was applied again, and the CG continued to perform the traditional method, "paper and pen", and EG developed the test in the Edpuzzle application downloaded on each students smartphone.

The execution phase of the quasi-experiment was carried out in disciplines from all periods of the Accounting course, taking place between the months of October and December 2019, with the participation of 164 students, with this research previously approved by the Committee Standing Committee on Ethics in Research Involving Human Beings at the State University of Maringá, under opinion No. 3.635.784 and CAAE 21921019.9.0000.0104. In the subject of general accounting I (1st year), the theme of the video was equity. In budgetary and governmental accounting (2nd year), the theme was fiscal balance. In the analysis of the financial statements (3rd year), the content was related to the analysis of working capital and the scissors effect. And finally, in the discipline of auditing and accounting expertise (4th year), the video dealt with the introduction to accounting expertise.

The content worked in each discipline was unprecedented for the students and were previously agreed with the teachers of the disciplines. Each teacher accessed the Edpuzzle virtual classroom with their registration data, being assisted by the researchers who followed each step and assisted in the editing of the videos and formulation of the quizzes. An execution schedule was then drawn up, from the preparation of the material with the teacher to the application of the tests. Due to scheduling of the Academic Activity Plan (PAA), the pre-test was conducted in October in the disciplines of Analysis of Financial Statements, General Accounting I and Budgetary and Governmental Accounting, in that order. Similarly, in the Accounting Expertise discipline, both the pre-test and the post-test were carried out in December 2019. It should be noted that all classes were in the evening and, with the exception of General Accounting I, all subjects were conducted by the same teachers in the two classes of each school year.

In general, there was no difficulty in applying the pre-test in any of the periods of the course. All students agreed to participate in the research. Shortly after the study was explained, the students signed the Free and Informed Consent Form (ICF). In general, all students endeavored to answer all questions.

\subsubsection{Data analysis}

Statistical analyzes were performed using software R version 4.0.2 (R Core Team, 2020), in a sample of 164 students from the Accounting Sciences course at Brazilian public institution. Descriptive analyzes of the students academic profile were carried out to compare performance, verified through the test scores. The t-Student test was performed to compare means, and to observe normality and independence of the data, the Shapiro-Wilk and Cox-Stuart tests were used, respectively, essential conditions for the realization of the t-Student test. In cases where the normality hypothesis was violated, the Mann-WhitneyWilcoxon $\mathrm{U}$ test was used, considering the $5 \%$ significance in all tests.

\section{Results and Discussion}

Initially, in order to meet the essential statistical assumptions, the hypothesis of normality of the variable "grades" was tested for classes belonging to the control and experimental groups. The hypothesis of normality was rejected for the post-test scores of the GC Accounting Expertise discipline (p-value < 0.05). For the other pre-tests and post-tests conducted in the disciplines, the Shapiro-Wilk tests confirm data normality (p-value > 0.05). The Cox-Stuart test was also carried out, which points out the independence of information for the pre-tests and post-tests conducted in all disciplines, both for the 
demonstrated CG and for the EG (p-value > 0.05). After establishing the assumptions of normality, the analyzes were continued, describing the performance of the students in the pre-test and post-test tests. In order to extract initial information about the students performance, descriptive analyzes were carried out for both experimental and control classes. Table 2 shows the average of the pre-test and post-test scores for the subjects General Accounting I, Budgetary and Governmental Accounting, Analysis of Financial Statements and Accounting Expertise, related to the CG. It is observed that the classes present a higher average in the scores of the post-test when compared with the pre-test.

Table 2. Mean and standard deviation of the pre-test and post-test scores of the control group.

\begin{tabular}{lccc}
\hline & Pre-test & Post-test & $\begin{array}{c}\text { Pre-test vs } \\
\text { Post-test }\end{array}$ \\
\hline \multicolumn{1}{c}{ Courses } & Mean \pm standard deviation & Mean \pm standard deviation & $\begin{array}{c}\text { Difference of } \\
\text { means }\end{array}$ \\
\hline $\begin{array}{l}\text { General Accounting I } \\
\text { Budgetary and } \\
\text { Governmental Acc. }\end{array}$ & $5.80(3.87-7.73)$ & $7.25(5.24-9.26)$ & -1.45 \\
$\begin{array}{l}\text { Analysis of Financial } \\
\text { Statements }\end{array}$ & $2.26(0.56-3.96)$ & $2.73(1.16-4.30)$ & -0.47 \\
Accouting Expertise & $6.45(5.49-7.39)$ & $7.63(6.84-8.42)$ & -1.18 \\
\hline
\end{tabular}

Source: Authors.

For the experimental classes, the pre-test and post-test scores of the subjects of General Accounting I, Budgetary and Governmental Accounting, Analysis of Financial Statements and Accounting Expertise were observed. Table 3 clearly shows that there was an average increase in the initial pre-test scores and the final scores obtained in the post-test conducted, as occurred in the control class.

Table 3. Mean and standard deviation of the pre-test and post-test scores of the experimental group.

\begin{tabular}{lccc}
\hline & Pre-test & Post-test & $\begin{array}{c}\text { Pre-test vs } \\
\text { Post-test }\end{array}$ \\
\hline \multicolumn{1}{c}{ Courses } & Mean \pm standard deviation & Mean \pm standard deviation & $\begin{array}{c}\text { Difference of } \\
\text { means }\end{array}$ \\
\hline $\begin{array}{l}\text { General Accounting I } \\
\text { Budgetary and }\end{array}$ & $6.20(4.83-7.57)$ & $7.00(5.04-8.96)$ & -0.80 \\
$\begin{array}{l}\text { Governmental Acc. } \\
\text { Analysis of Financial }\end{array}$ & $3.62(2.08-5.16)$ & $3.93(1.89-5.97)$ & -0.31 \\
$\begin{array}{l}\text { Statements } \\
\text { Accouting Expertise }\end{array}$ & $5.98(5.00-6.96)$ & $6.29(5.16-7.42)$ & -0.31 \\
\hline
\end{tabular}

Source: Authors.

In cases where the variables under study presented the hypothesis of satisfied normality and independence, the $\mathrm{t}$ Student test was used, and the results can be seen in Table 4. Thus, in order to meet the general objective of the research, which seeks to verify the influence of the use of digital videos through the technological tool Edpuzzle in the performance of students of Accounting Sciences, we proceeded with the statistical analyzes between the experimental and control groups. 
Table 4. Students t-test for comparing means between the pre-test and the post-test of the control group and between the pre-test and the post-test of the experimental group.

\begin{tabular}{lcccc}
\hline & \multicolumn{2}{c}{ Control Group } & \multicolumn{2}{c}{ Experimental Group } \\
\hline \multicolumn{1}{c}{ Courses* } & Test statistic & P-value & Test statistic & P-value \\
\hline General Accounting I & -2.04 & 0.08 & -1.30 & 0.20 \\
Budgetary and & -0.77 & 0.44 & -0.48 & 0.62 \\
Governmental Acc. & -2.04 & 0.06 & -1.08 & 0.28 \\
Analysis of Financial Statements & & & \\
\hline
\end{tabular}

*P-value considered significant $<0.05$. Source: Authors.

The Student t-test points out that there were no significant differences, on average, in the subjects, for both the CG and the EG, between the pre-test and post-test performances (p-value >0.05). Such results demonstrated that the video conducted in Edpuzzle did not generate significant differences in the student performance of the EG, the same occurring with traditional teaching. On the one hand, there is the traditional teaching system, in which the CG was submitted, considered by Oliveira (2014) as a method in which the teacher is considered the main "resource" for the teaching and learning process. On the other hand, the EG, formed by students submitted to the use of technology, also did not present significant differences in their average grades. According to Watty et al. (2016), the acceptance of the use of technologies by students of Accounting Sciences can occur in a more paced way, considering that the adoption of technological resources in accounting education is slow, and that many professors are still reluctant to use them.

Although a vast literature points out that the use of video has positive effects on the performance of students (D'Aquila et al., 2019), on the other hand, there were contrary positions on the part of students regarding the use of technologies in formal learning contexts ( Salaway, Caruso \& Nelson, 2007), also verifying small relationships between the use of technology and the productivity of learning (Thompson, 2013). Therefore, it is stated that for the sample of this research, the effectiveness of the use of technology did not surpass traditional teaching methods, which corroborates with the finding by Nicol et al. (2018).

Videos are effective in learning (Holtzblatt \& Tschakert, 2011; D'Aquila et al., 2019), with Generation Z being the main enthusiast in the use of such resources, given that traditional teaching models no longer fully serve this new generation (Vaughan, 2014). This reality could not be verified regarding the performance of the students in this research. It is suggested that temporal and sampling problems may have influenced the results obtained, and some points to be reflected on and discussed about these verifications are raised below.

Firstly, it should be noted that previous quasi-experimental research that repeatedly made use of digital video in Edpuzzle, that is, longitudinal studies, allowed the student to adapt to the technology and conduct it easily, obtaining better performance when compared to the group of students control (Alastuey \& Galar, 2017; Karaca \& Ocak, 2017), however, this reality differed from this study.

Positive results regarding performance and the use of technology, in quasi-experimental studies in the Brazilian reality, have also been observed (Quintana, 2015). Even though students had contact only once with video technology in Edpuzzle, this could have influenced performance, given the current transition process experienced in current education (Oliveira, 2014). It is worth mentioning that, although the present literature tends towards promising results regarding the use of technologies in teaching, it is observed the existence of recent studies that corroborate the results of this research (Thompson, 2013; Nicol et al., 2018).

Videos are effective in learning (Holtzblatt \& Tschakert, 2011; D'Aquila et al., 2019), with Generation Z being the main enthusiast in the use of such resources, given that traditional teaching models no longer fully serve this new generation 
(Vaughan, 2014). This reality could not be verified regarding the performance of the students in this research. It is suggested that temporal and sampling problems may have influenced the results obtained, and some points to be reflected on and discussed about these verifications are raised below.

Firstly, it should be noted that previous quasi-experimental research that repeatedly made use of digital video in Edpuzzle, that is, longitudinal studies, allowed the student to adapt to the technology and conduct it easily, obtaining better performance when compared to the group of students control (Alastuey \& Galar, 2017; Karaca \& Ocak, 2017), however, this reality differed from this study. Positive results regarding performance and the use of technology, in quasi-experimental studies in the Brazilian reality, have also been observed (Quintana, 2015). Even though students had contact only once with video technology in Edpuzzle, this could have influenced performance, given the current transition process experienced in current education (Oliveira, 2014). It is worth mentioning that, although the present literature tends towards promising results regarding the use of technologies in teaching, it is observed the existence of recent studies that corroborate the results of this research (Thompson, 2013; Nicol et al., 2018).

Another point to be considered refers to the profile of the sample, given that student involvement in the classroom creates an effective learning environment and is an indicator of student performance (Handelsman, Briggs, Sullivan \& Towler, 2005; D ' Aquila et al., 2019). It was observed, especially in the experimental group of the General Accounting class I, a great lack of interest from the students with the proposed test to be carried out in the application, confirming Wang, Bergin \& Bergin, (2014), who affirm that the low level of involvement of the class leads to negative performance effects. In the Analysis of Financial Statements class, the professor of the discipline affirmed, after the application of the quasi-experiment, that the experimental group always presented performance results much lower than the control group, which can be clearly observed in the average difference of the scores, having in view that the previous academic performance has a direct effect on the current performance (Guney, 2009). In a complementary way, researches carried out in the accounting area show that the grades that students obtained in the past are related to their future performance (Eskew \& Faley, 1988).

As for the Budgetary and Governmental Accounting discipline, it was found that the participants in this sample had the lowest number of hours of study per week in relation to the other groups. Thus, it is assumed that there is a direct relationship between the number of hours the student dedicates to studies to his performance (Guney, 2009). And yet, it was the discipline that obtained the lowest average score in the pre-test conducted, reflected in both the EG and the CG, and it should be considered that there is a positive relationship between prior knowledge and performance in accounting courses (Uyar \& Güngörmüş, 2011). As a result of the results found, the research hypothesis H1 (Students submitted to the use of digital technologies have greater performance in classroom activities) was not confirmed, considering that there were no significant differences in performance for students submitted to the use of digital technologies. In order to verify whether there were statistically significant differences between the pre-test and the post-test of the CG compared to the EG, the normality of the means previously found was tested, being confirmed by the Shapiro-Wilk test, according to Table 5 (p-value > 0.05).

Table 5. Shapiro-Wilk test of normality of differences in means of the pre-test and post-test variables of the control and experimental groups.

\begin{tabular}{lcccc}
\hline & \multicolumn{2}{c}{ Control Group } & & Experimental Group \\
\hline Difference of means* & Test statistic & P-value & Test statistic & P-value \\
\hline \multirow{2}{*}{ Pre-test vs Post-test } & 0.96 & 0.79 & 0.85 & 0.24 \\
\hline
\end{tabular}

*P-value considered significant $<0.05$. Source: Authors. 
Thus, the t-Student test, shown in Table 6, demonstrates that for a 5\% significance level (p-value >0.05) there were no statistically significant differences between the pre-tests and the post-tests conducted in the CG and EG. This test was carried out with the intention of confirming whether the average grades obtained between the CG and the EG would or not differ, and it was confirmed once again that, like the EG, the control group also did not show improvements. However, there is a wide literature stating that students present satisfactory stimuli when using digital videos and react positively to this teaching method (Holtzblatt and Tschakert, 2011; D'Aquila et al., 2019), as shown by good performance with the use of Edpuzzle (Alastuey \& Galar, 2017). Similarly, smartphones have contributed to the teaching and learning process due to their easily accessible and mobile resources (Barragán et al., 2016).

The technologies that were part of this study have shown good results in past studies. Therefore, it is possible to state that, although this research has not found improvements in performance with the use of the aforementioned technologies, it is the first step to be taken, considering that the use of the technologies studied here can be a positive path to be followed, taking into account considering that human behavior goes through some evolutionary steps in the face of new information, one of which is resistance to changes, which leads to the need for adaptation by students and teachers (Oliveira, 2014).

Table 6. Student t-test for differences in means regarding the pre-test and post-test variables of the control group and the experimental group.

\begin{tabular}{cc}
\hline Pre-test vs Post-test & Test statistic \\
\hline Difference of means* & -2.43 \\
\hline
\end{tabular}

*P-value considered significant $<0.05$. Source: Authors.

In the event that the hypothesis of normality of the variable under study was violated, the U Mann-Whitney-Wilcoxon test was used, and it can be observed in Table 7 that there are no significant differences in the discipline of Accounting Expertise, between the performances of the pre- test and post-test of CG and EG (p-value>0.05). Such checks go according to the profile of the sample, in which both classes presented similar performances both in the pre-test and in the post-test, and this was the discipline with the highest number of hours of weekly study among the students.

It is also worth mentioning that the aforementioned discipline presented better results both in the pre-test and in the post-test conducted at the GE, again confirming that students with previous knowledge about the content perform better than those who do not (Koh \& Koh, 1999). The content of the video conducted in Edpuzzle may not have caused a positive impact on performance, especially considering the specific problems that occurred during the conduct of the post-test, such as class time, internet and the absence of the teacher during the application of the test in Edpuzzle. The researcher was able to observe that this would be a discipline with expressive potential for the use of videos in Edpuzzle.

Table 7. Mann-Whitney-Wilcoxon $U$ test between the pre-test and the post-test of the control group and between the pre-test and the post-test of the experimental group.

\begin{tabular}{lcccc}
\hline & & Control Group & \multicolumn{2}{c}{ Experimental Group } \\
\hline Courses* & Test statistic & P-value & & Test statistic \\
\hline Accouting Expertise & 122.14 & & 0.31 & 141.50 \\
\end{tabular}

*P-value considered significant $<0.05$. Source: Authors. 
Table 8 shows that there are no significant differences in the Accounting Expertise discipline, between the performances of the CG post-test with the EG post-test (p-value > 0.05). Although the use of videos in Edpuzzle was not effective immediately upon first contact, observations in this regard should be made, as Oliveira (2016) states that it is necessary to adapt both teachers and students so that the adoption of new technological resources is viewed positively and assist in performance.

Table 8. Mann-Whitney-Wilcoxon $U$ test between the post-test of the control group and the post-test of the experimental group.

\begin{tabular}{lll}
\hline Courses $^{*}$ & Test statistic & P-value \\
\hline Accouting Expertise & 112.50 & 0.64 \\
\hline
\end{tabular}

*P-value considered significant $<0.05$. Source: Authors.

A crossover was also carried out between the averages obtained between the CG and the EG, with the intention of observing whether the average differences could reflect significant differences between the groups. Table 9 shows the average differences obtained between the CG and EG, and it may be possible to infer that, except in the discipline of Analysis of the Financial Statements of the CG, which presented a profile of a class with a higher previous academic performance when compared to the EG, there is an effect direct impact on academic performance (Guney, 2009). All others had higher means for the EG. It is observed that the averages between the CG and EG during the conduct of the pre-test show little difference, therefore, each group with similar prior knowledge, which is a factor that closely reflects on the students performance (Miranda et al., 2015).

Table 9. Difference of means between pretest of the control group with pretest of the experimental group.

\begin{tabular}{lccc}
\hline \multicolumn{1}{c}{ Courses } & Control Group & Experimental Group & Difference of means \\
\cline { 2 - 4 } & Pre-test means & Post-test means & -0.40 \\
\hline $\begin{array}{l}\text { General Accounting I } \\
\text { Gudgetary and }\end{array}$ & 5.80 & 6.20 & -1.36 \\
\hline $\begin{array}{l}\text { Analysis of Financial } \\
\text { Statements }\end{array}$ & 2.26 & 3.62 & 0.47 \\
\hline Accouting Expertise & 6.45 & 5.98 & -1.44 \\
\hline
\end{tabular}

Source: Authors.

A crossover was also drawn between the averages obtained in the post-test scores of the CG and post-test of the EG, as shown in Table 10. Having already taken into account the fact that they had a lesson on the content of the test, it can be observed although, the average performance of the General Accounting class I started to be higher in the post-test in the CG, which was already expected, due to the lack of interest shown by the academics during the conduct of the post-test in the Edpuzzle application. Furthermore, since it is a first-year class, some variables that directly influence performance should be considered, such as the students confidence in their abilities, perception of the role of the university and the desire to experience intellectual growth (Byrne and Flood, 2008). This is intrinsically linked to the adaptation process, not only of the technologies in the classroom, but of the new scenario that they start to experience (Oliveira, 2016), thus, the reflexes of this transition was directly reflected in the students behavior and on their performance in the classroom post-test. 
Table 10. Difference of means between post-test in the control group and post-test in the experimental group.

\begin{tabular}{lccc}
\multicolumn{1}{c}{ Courses } & Control Group & Experimental Group & $\begin{array}{c}\text { Difference of } \\
\text { means }\end{array}$ \\
\cline { 2 - 4 } & Pre-test means & Post-test means & 0.25 \\
\hline General Accounting I & 7.25 & 7.00 & -1.20 \\
\hline $\begin{array}{l}\text { Budgetary and } \\
\text { Governmental Acc. }\end{array}$ & 2.73 & 3.93 & 1.34 \\
\hline $\begin{array}{l}\text { Analysis of Financial } \\
\text { Statements }\end{array}$ & 7.63 & 6.29 & -0.17 \\
\hline Accouting Expertise & 7.00 & 7.17 & \\
\hline
\end{tabular}

Source: Authors.

In order to verify whether such differences between the crossing of the average grades present significant differences, we proceeded with the Shapiro Wilk test, being verified that the assumptions of normality were met for both the differences between the CG and the EG, with (p-value = 0.37) for the control group, and (p-value $=0.97$ ) for the experimental group. From Table 11, it is possible to verify by means of the t-Student test that there are no significant differences between the crossing of the average grades (p-value> 0.05), of the CG and EG. Although there were small differences in the pre-test and post-test means, both in the control group and in the experimental group, such differences are not significant.

Table 11. Student t-test to compare whether there are differences between the pre-tests in the control and experimental group with the post-tests in the control and experimental group.

\begin{tabular}{ccc}
\hline & \multicolumn{2}{c}{ Pre-test vs Post-test } \\
\hline & Test statistic & P-value \\
\hline Difference of means* & -1.06 & 0.32 \\
\hline
\end{tabular}

*P-value considered significant $<0.05$. Source: Authors.

\section{Conclusion}

The present study aimed to verify the influence of the use of digital videos, through the technological tool Edpuzzle, on the performance of students of Accounting Sciences of a Brazilian public education institution. In this regard, a quasiexperimental study was carried out in order to observe the averages and average differences in grades obtained between classes that used technology, the experimental group, and those that did not, these being the control group. The results showed that the use of technology did not improve the grades of the students in the experimental group, as well as there was no progress in the control group, whose average grades did not show statistically significant differences. Therefore, the hypothesis (H1) was not confirmed, considering that the students submitted to the use of digital technologies did not present a greater performance in the activities.

Although the findings of the present study did not find significant differences in the students performance, with the use of the studied technology, it is encouraged that further investigations in this regard should be carried out, considering, for example, a longer follow-up time during application of this quasi-experiment, considering that several authors support the claim that videos are considered a powerful resource in education and that it depends on the permissibility of both teachers and students so that the positive effects begin to prevail (Pires, 2016 ). The results verified here generate reflections to be analyzed in relation to the present pedagogical model, being consistent with the statement by Oliveira (2016) that the current teaching 
has been going through a transition process, in which, for the technologies to be effective, both teachers, as the students, must go through their adaptation periods. Overcoming the obstacles that prevent the advancement of technologies in education is a real challenge today, and in accounting education is no different.

The main limitations of the study are highlighted below: (1) methodological decisions caused time restriction for application of the quasi-experiment, the short period that students had contact with technology was a limiting factor, which is also a restriction reported by students participants; (2) the lack of interest of some students compromised the analyzes, in some cases there was a need to eliminate them from the sample; (3) Edpuzzle is currently only available in the English language, being a limitation for some students, mainly for the initial installation of the application; (4) in several cases, the Edpuzzle operating system did not recognize certain words in the Portuguese language, automatically changing some of them, making the questions and/or alternatives become meaningless; (5) the Edpuzzle smartphone application has limitations when handling videos and quizzes concurrently, and the same was not observed when using it on computers or notebooks.

It is suggested, therefore, that more practical investigations be carried out, considering that the present study also did not identify significant differences in performance for students who did not use the videos in Edpuzzle (control group), except for the discipline of the Analysis of Financial Statements. This result provides information about the current traditional teaching, which motivates more investigations involving resources that make sense to Generation Z, and in this context, Edpuzzle represents one of these mechanisms that should continue to be explored on the most different educational fronts.

For future work, it is suggested to carry out an extension of this study, considering the initial findings verified here. Thus, it is recommended to carry out a quasi-experiment with the same subjects or related subjects verified by this research, thus outlining a profile of acceptability and performance by subject regarding the use of videos in Edpuzzle, maintaining the same logic of the control and experimental groups, however, it is recommended that the study be carried out in a longitudinal manner, at least if there is the monitoring of two or three contents on a continuous basis.

This study intends to be a source of encouragement for more research to be developed, in order to identify methodologies that are in fact effective for the current teaching reality. Positive results in terms of performance have already been identified when using videos in Edpuzzle (Alastuey \& Galar, 2017; Karaca and Ocak, 2017), however, previous studies that sought to measure student performance when using videos in Edpuzzle in courses accounting, mainly in the national literature, were not identified, therefore, gaps to be explored.

\section{References}

Afach, S. A., Kiwan, E., \& Semaan, C. (2018). How to enhance awareness on bullying for Special Needs Students using "Edpuzzle" a web 2.0 tool. International Journal of Educational Research Review, 3(1), 1-7.

Alvarado, N. C., Coelho, D., \& Dougherty, E. (2016). Mobile apps for ELLs: Supporting language learning with engaging digital tools. Argentinian Journal of Applied Linguistics, 4(1), 43-58.

Apostolou, B., Dorminey, J. W., Hassell, J. M., \& Watson, S. F. (2013). Accounting education literature review (2010-2012). Journal of Accounting Education, 31(2), 107-161.

Baker, A. (2016). Active learning with interactive videos: Creating student-guided learning materials. Journal of Library \& Information Services in Distance Learning, 10(3-4), 79-87.

Barragán, A. C., Martín, A. S., \& Peralta, A. L. (2016). Análisis del Smartphone como herramienta de apoyo en la formación académica de alumnos universitarios. Pistas educativas, 38(122).

Berwanger, P. M. (2019). Aprender e ensinar na era digital: um estudo sobre Mobile Learning emexperiênciasde avaliação de aprendizagem na Educação Superior.

Booth, P., Luckett, P., \& Mladenovic, R. (1999). The quality of learning in accounting education: the impact of approaches to learning on academic performance. Accounting Education, 8(4), 277-300.

Byrne, M., \& Flood, B. (2008). Examining the relationships among background variables and academic performance of first year accounting students at an Irish University. Journal of Accounting Education, 26(4), 202-212. 
Cozby, P. C., \& Bates. S. (2012). Methods in behavioral research (11 th ed.).

Cruz, C. V. O. A., Corrar, L. J., \& Slomski, V. (2008). A docência e o desempenho dos alunos dos cursos de graduação em contabilidade no Brasil. Contabilidade Vista \& Revista, 19(4), 15-37.

D’Aquila J. M., Wang, D., \& Mattia, A. (2019). Are instructor generated YouTube videos effective in accounting classes? A study of student performance, engagement, motivation, and perception. Journal of Accounting Education, 47, 63-74.

da Silva, B. G., de Moraes, T. E. N. T., da Costa, A. C., \& Vieira, A. M. C. (2020). Percepção e satisfação no uso do aplicativo edpuzzle utilizando análise fatorial exploratória. Research, Society and Development, 9(12), e26391211065-e26391211065.

Eskew, R. K., e Faley, R. H. (1988). Alguns determinantes do desempenho dos alunos no primeiro curso de contabilidade financeira de nível universitário. Accounting Review, 137-147

Fleming, N. D. (1995). I'm different, not dumb. Modes of presentation (VARK) in the tertiary classroom. In: Zelmer, A. (Ed.), Research and development in higher education, proceedings of the 1995 annual conference of the higher education and research development society of Australasia (HERDSA) (Vol. 18, pp. 308-313).

Gall, M. D., Gall, J. P., \& Borg, W. R. (2003). Educational research: An introduction (7th ed.). Allyn \& Bacon.

Graham, K. (2016). TechMatters: Let's Get Interactive, (Videos That Is), with EdPuzzle and Vialogues. LOEX Quarterly, $43(1), 3$.

Guney, Y. (2009). Fatores exógenos e endógenos que influenciam o desempenho dos alunos nos módulos de contabilidade de graduação. Educação Contábil, $18(1), 51-73$.

Handelsman, M. M., Briggs, W. L., Sullivan, N., \& Towler, A. (2005). A measure of college student course engagement. The Journal of Educational Research, 98(3), 184-192.

Holtzblatt, M., Tschakert, N. (2011). Expanding your accounting classroom with digital video technology. Journal of accounting education. 29 , $100-121$.

Karaca, C., \& Ocak, M. A. (2017). Algoritma ve programlama eğitiminde ters yüz öğrenmenin üniversite öğrencilerinin akademik başarısına etkisi. International Online Journal of Educational Sciences, 9(2), 527-543.

Koh, M. Y., \& Koh, H. C. (1999). The determinants of performance in an accountancy degree programme. Accounting Education, 8(1), 13-29.

Kolås, L. (2015). Application of interactive videos in education. International Conference on Information Technology Based Higher Education and Training (ITHET). IEEE, (1-6).

Laaser, W., \& Toloza, E. A. (2017). The changing role of the educational video in higher distance education. The International Review of Research in Open and Distributed Learning, 18(2).

Lillie, R. E., Wygal. D. E. (2011). Virtual Office Hours (VOH) in accounting coursework: Leveraging technology to enhance an integrative learning environment. Journal of accounting education. 29, 1-13.

Magdalena, SM (2015). A relação entre estilos de aprendizagem, comportamento de aprendizagem e resultados de aprendizagem nos estudantes romeno. Procedia-Social and Behavioral Sciences, 180, 1667-1672.

Mischel, L. J. (2018). Watch and Learn? Using EDpuzzle to Enhance the Use of Online Videos. Management Teaching Review, 1-7.

Moran, M., Seaman, J., \& Tinti-Kane, H. (2011). Teaching, Learning, and Sharing: How Today's Higher Education Faculty Use Social Media. Babson Survey Research Group.

Nasu, V. H.(2017). O efeito do sistema de resposta do estudante (SRE) sobre o desempenho acadêmico e a satisfação discente: um quase-experimento com alunos de Ciências Contábeis. Dissertação de mestrado, Departamento de contabilidade e atuária. Faculdade de Economia, Administração e Contabilidade da Universidade de São Paulo, São Paulo Brasil.

Nicol, A. A., Owens, S. M., Le Coze, S. S., MacIntyre, A., \& Eastwood, C. (2018). Comparison of high-technology active learning and low-technology active learning classrooms. Active Learning in Higher Education, 19(3), 253-265.

Oliveira, R. A. D. (2014). Potencialidades e dificuldades no uso dos tablets como ferramenta didática: O estado da arte das pesquisas. Dissertação de mestrado, Universidade Católica de São Paulo, São Paulo, Brasil.

Palma, L. O., Tobías, P. J. B., Prieto, M. C., León, F. J. M., \& Ruiz, Á. A. M. (2018). Use of Kahoot and EdPuzzle by Smartphone in the Classroom: The Design of a Methodological Proposal. International Workshop on Learning Technology for Education in Cloud, $37-47$.

Pasiar, L. (2018). Využitie mobilného vzdelávania vo vyučovaní Using of Mobile Learning in Education. Schola nova, quo vadis, $127-136$.

Phang, M. M., Johl, S. K., \& Cooper, B. J. (2014). Goalefficacy framework: an examination of domestic and international accounting students' academic performance. Accounting \& Finance, 54(4), 1295-1318.

Pires, A. I. T. (2016). O papel de um estúdio de televisão digital na conceção, organização e difusão de RED numa escola de ensino secundário. Tese de Doutorado, Especialidade em Tecnologia da Informação e Comunicação. Universidade de Lisboa. Portugal.

Prieto C. C., Santos S. M. J., Hernández E. A., Moreno, M., Rodríguez P. C., \& Queiruga-Dios, A. (2016). Dispositivos móviles como instrumentos para la adquisición de competencias en materias de Ciencias. VI Jornada de innovación docente de la universidad de valladolid, 7-11. 
Research, Society and Development, v. 10, n. 5, e9010514561, 2021

(CC BY 4.0) | ISSN 2525-3409 | DOI: http://dx.doi.org/10.33448/rsd-v10i5.14561

Pueo, B., Jimenez-Olmedo, J. M., Penichet-Tomás, A., \& Carbonell Martínez, J. A. (2017). Aplicación de la herramienta EDpuzzle en entornos de aprendizaje individuales dentro del aula.

Quintana, A. C. (2015). Tecnologias da eduacação: Identificando o reflexo do chat e forum de discussão no processo de aprendizagem no ensino superior. Tese de doutorado, Departamento de contabilidade e atuária. Faculdade de Economia, Administração e Contabilidade da Universidade de São Paulo. São Paulo, Brasil.

R Core Team. (2020). R: a language and environment for statistical computing. R Foundation for Statistical Computing.

Salaway, G., Caruso, J. B., \& Nelson, M. R. (2007). The ECAR study of undergraduate students and information technology, 2007. Boulder, Colorado: Educause Center for Applied Research.

Serçemeli, M., Günbaş, N., \& Baydaş, Ö. (2018). Using flipped classroom approach in computerized accounting education. World of Accounting Science, 20(4).

Sharoff, L. (2011). Integrating YouTube into the Nursing Curriculum. OJIN: The Online Journal of Issues in Nursing, 16(3).

Singh, A. (2014). Challenges and issues of Generation Z. IOSR Journal of Business and Management, 16(7), 59-63.

Singh, V., Abdellahi, S., Maher, M. L., \& Latulipe, C. (2016). The video collaboratory as a learning environment. In Proceedings of the 47th ACM Technical Symposium on Computing Science Education (pp. 352-357). ACM.

Smith, M. (2003). Research methods in accounting. London: Sage.

Thompson, P. (2013). The digital natives as learners: Technology use patterns and approaches to learning. Computers \& Education, 65, 12-33.

Uyar, A., \& Güngörmüs, A. H. (2011). Factors Associated with Student Performance in Financial Accounting Course. European Journal of Economic \& Political Studies, 4(2) 139-154.

Vaughan, M. (2014). Flipping the learning: An investigation into the use of the flipped classroom model in an introductory teaching course. Education Research and Perspectives, 41, 25-41.

Wang, Z., Bergin, C., \& Bergin, D. A. (2014). Measuring engagement in fourth to twelfth grade classrooms: The Classroom Engagement Inventory. School Psychology Quarterly, 29(4), 517.

Watty, K., McKay, J., \& Ngo, L. (2016). Innovators or inhibitors? Accounting faculty resistance to new educational technologies in higher education. Journal of Accounting Education, 36, 1-15.

Waycott, J., Bennett, S., Kennedy, G., Dalgarno, B., \& Gray, K. (2010). Digital divides? Student and staff perceptions of information and communication technologies. Computers \& Education, 54(4), 1202-1211.

Williams, A. (2015). Move over, millennials, here comes Generation Z. The New York Times, 18 